\title{
Early Morphological Growth Response and Incidence of Key Pests Under Two Spacing Regimes of Coffea canephora
}

\author{
Godfrey Sseremba ${ }^{1 *}$, Godfrey Hubby Kagezi ${ }^{1)}$, Judith Kobusinge ${ }^{1)}$, David Akodi ${ }^{1)}$, Nicholas \\ Olango $^{1)}$, Joseph Mulindwa' ${ }^{1)}$, Pascal Musoli ${ }^{1)}$, and Geofrey Arinaitwe ${ }^{1)}$

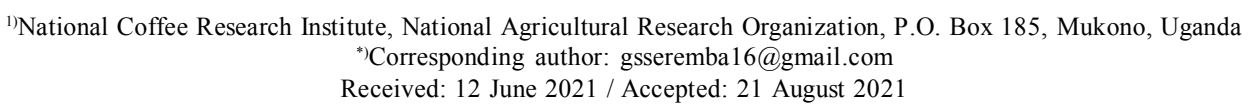

\begin{abstract}
Coffea canephora has non-limiting but unexploited yield and quality potential when compared with $C$. arabica. Coffee tree density optimization can improve fortunes of smallholder farmers. An attractive example is that high productive countries where high plant densities do increase area yield but across board recommendations are illogical especially with variety and agroecological variations. We aimed to compare two spacing regimes for growth response and pest incidence using Kituza Robusta clone. Randomized complete block designs with three replications and eight plants per plot were established at four agroecologically diverse on-farm locations. Eleven plant growth variables were measured. In addition incidences of five key pests were assessed. Data was collected on a 3-month interval starting from 12 up to 21 months after planting. Highly significant differences between spacing regimes $(p<0.01)$ were obtained for majority of variables. Mean growth response was generally higher under $3 \mathrm{~m} \mathrm{x} 1 \mathrm{~m}$ (high density) than $3 \mathrm{mx}$ $3 \mathrm{~m}$ (low density) particularly with stem girth, plant height, length of longest primary branch, and leaf blade length. Conversely, pest incidence of black coffee twig borer, leaf eating beetles, leaf miners, and tailed caterpillars, except skeletonizers was higher under high than low plant densities. The findings provide a guide on implications of high plant densities on growth robustness which is translatable into yield potential; amidst a pest prevalence dilemma in studied type of $C$. canephora.
\end{abstract}

Keywords: coffee tree density, stable growth traits, plant population, pest dynamics, Xylosandrus compactus

\section{INTRODUCTION}

Coffee (Coffea spp.) is the most traded beverage worldwide by volume and monetary value. The crop has two major commercial species, Coffea arabica (Arabica coffee) and Coffea canephora (Robusta coffee). C. arabica is the most traded owing to its intrinsic superior quality, wider global geographical adaptation and adoption, and supportive research-based production and post-harvest enhancement technologies.
C. arabica contributed $64 \%$ of the global coffee trade and C. canephora contributed $36 \%$ of total 130 million bags in year 2020/ 2021 (ICO, 2021). In Uganda, C. canephora production is dominant, contributing about $80 \%$ of the coffee exports compared to $20 \%$ by $C$. arabica (ICO and UCDA, 2019; Musoli et al., 2019; UCDA, 2019; Uganda Coffee Federation, 2017). C. canephora is genetically more diverse than C. arabica (Aluka, 2013; Labouisse et al., 2008; Leroy et al., 2014; Merot L'anthoene et al., 2019; Musoli 
et al., 2009) and its trees are more robust and more productive of Uganda's.

Potential yield of $C$. canephora is estimated at 5 tons/ha yet in sub-Saharan Africa where smallholder farmers produce $80 \%$ of the crop, only $0.6 \mathrm{t} / \mathrm{ha}$ is realized (Bote, 2016; Geneti, 2019; Wang et al., 2015). Beside genetic potential (Egonyu et al., 2015b; Ferguson et al., 2011; Frasca et al., 2014; Geneti, 2019; Musoli et al., 2009), poor agronomic practices account for loss of over $50 \%$ of a variety yield potential (Boreux et al., 2016; Kagezi et al., 2014; Owere et al., 2014; Wang et al., 2015). Plant spacing and number of stems per plant is a priority driver of productivity (Sseremba et al., 2021). Plant density influences mechanizability of field operations, soil fertility and shading intensity optimization; with potential to condition yield and pest and disease incidences (Biruk, 2018; Boreux et al., 2016; Bukomeko et al., 2018; Kagezi et al., 2013; Matovu et al., 2013; Wagner et al., 2019).

Understanding systematic interactions between coffee plant density and biotic stress levels in a geographical location is prerequisite to designing the most appropriate matrix of agronomic practices that bring out the best coffee tree yield and bean quality. Recommendation on spacing regimes in C. canephora vary according to growth robustness of available varieties and number of stems retained per tree (Kibirige-Ssebunya et al., 1993; Njoroge et al., 1992; Razaq et al., 2012; Rezende et al., 2014). In Uganda, farmers have since the $1960 \mathrm{~s}$ been recommended to use $3 \mathrm{~m} \times 3 \mathrm{~m}$ and retain three or four stems per tree. These recommendations differ from those of leading Robusta coffee producers like Brazil and Vietnam (Ferrão et al., 2019; Pereira et al., 2013; Rakocevic et al., 2014; Rodrigues et al., 2016, 2014). For instance, most of Brazilian farmers opt for $3 \mathrm{~m} \times 1 \mathrm{~m}$ but maintain one stem per plant (Mekonnen et al., 2018). Contexts differ between Ugandan and the Brazilian Robusta coffee farmers, especially in terms of supportive agronomic practices and variety type (Musoli et al., 2019; Sseremba et al., 2021); and so, a comparative study of the Brazilian (3 m x $1 \mathrm{~m}$ ) and Ugandan ( $3 \mathrm{~m} \times 3 \mathrm{~m}$ ) spacing regimes was deemed essential before guiding stakeholders on possibility of tree density adjustments.

C. canephora varieties in Uganda exhibit a large horizontal growth, with primary branches extending up to $200 \mathrm{~cm}$ (Musoli et al., 2009, 2019; Aluka, 2013; Leroy et al., 2014; Merot L'anthoene et al., 2019). It implies that close spacing may lead to canopy overlap for the within row plants. As such, competition for light sets in; possibly compromising on photosynthetic efficiency (Sseremba et al., 2018) per tree. It can however, be argued that increase in tree density improves canopy cover thereby improving solar radiation use efficiency (Delaroza et al., 2017) especially if a plant will adjust elongation of its primary branches in lieu of phototropism such that within-row length reduces but it is compensated by between row extension of primaries.

Beside competition for light, increased plant densities can create conducive microenvironments for insect pests and diseases. Therefore, there is a likely increase in costs for pest management leading to profit reduction and if there is no matching budget for pest management then yield and quality can decline due to disease infection and pest damage. Humid conditions facilitated by increase in plant densities are largely responsible for severe infections of fungal pathogens like coffee wilt disease (Musoli et al., 2008, 2013), Armillaria root rot, coffee leaf rust and red blister (Luzinda et al., 2016; Matovu et al., 2013). The red blister disease is believed to become severe under moisture deficit and poor soil fertility conditions exacerbated by high plant densities. 
Key insect pests of C. canephora in Uganda include mealy bugs (Planococcus spp.), leaf eating beetles, green scales (Coccus spp.), leaf miners (Leucoptera spp.), coffee berry borer (Hypothenemus hampei), skeletonisers, tailed caterpillars and black coffee twig borer, Xylosandrus compactus (Eichhoff) (Kagezi et al., 2014; Magina et al., 2016). Movement of pests from one coffee plant to another is faster in high tree density than low density plantations (Boreux et al., 2016; Bukomeko et al., 2018; Kagezi et al., 2013; Legg et al., 2011). When pathogen microenvironments are created with increase in plant populations, there is a matching upsurge in some pests like the ambrosia beetles (especially, the black coffee twig borer) which enjoy a symbiotic relationship with some fungal infections (Egonyu et al., 2015; Kagezi et al., 2015).

The effects of variation in plant densities are primarily manifested as morphological growth responses prior to likely consequences of abiotic and biotic constraints and ultimate yield and quality adjustments. It is also necessary to ascertain if pest and disease incidence and damage/severity levels is dependent on morphological state of crop plants. Already, pruning for reducing number of shoots is documented to reduce coffee leaf rust and insect pests like tailed caterpillars and black coffee twig borer (Bukomeko et al., 2018; Kagezi et al., 2015b; Luzinda et al., 2016; Matovu et al., 2013; Pereira et al., 2013). Nevertheless Ugandan C. canephora farmers contend to increase yield from the current $600 \mathrm{~kg} \cdot \mathrm{ha}^{-1}$ to at least $1,800 \mathrm{~kg} \cdot \mathrm{ha}^{-1}$, premised on high tree density beyond the current population of 1,110 trees.ha ${ }^{-1}$. But in lieu of supportive agronomic practices and consequences of high tree density on pest incidence, the venture has become contentious. The objective of the study was to generate an insight on earlystage response in morphological growth and pest incidence of Robusta coffee contrast- ing plant densities. In this study, considered pests include black coffee twig borer, leaf eating beetles, leaf miners, skeletonisers and tailed caterpillars.

\section{MATERIALS AND METHODS}

\section{Study Sites and Planting Material}

The study was conducted in one on-station site located at the National Coffee Research Institute (NaCORI), Kituza campus, plus three on-farm sites located in Kyotera, Mitooma, and Mukono districts. Kituza, Kyotera, and Mukono sites lie close to Lake Victoria and the Equator, within the Lake Victoria crescent agro-ecological zone. Kituza and Mukono are north of the equator while Kyotera is on the south of the equator. Thborere site at NaCORI about $37 \mathrm{~km}$ east of Kampala. Mukono site is in Ntenjeru subcounty and about $53 \mathrm{~km}$ east of Kampala in the Lake Victoria Crescent, receiving annual mean rainfall of $2,015 \mathrm{~mm}$, annual mean temperature of $21.1^{\circ} \mathrm{C}$, relative humidity $77 \%$ and UV-index 0 . Kyotera site is about $180 \mathrm{~km}$ south of Kampala along Kampala-MasakaMutukula road in the cattle corridor side of Lake Victoria Crescent agroecological zone with average annual rainfall $1,738 \mathrm{~mm}$, temperature $30.4^{\circ} \mathrm{C}$, relative humidity $77 \%$, and UVindex 5. Mitooma is in the south of the Equator and lies in the southwestern rangeland agroecoogical zone, about $350 \mathrm{~km}$ west of Kampala. It receives an average annual rainfall of 905 $\mathrm{mm}$ (UBOS, 2020), temperature of $26^{\circ} \mathrm{C}$, relative humidity of $80 \%$ and $U V$-index of 6 . Nine months old rooted clonal cuttings of wilt disease resistant Robusta coffee (Coffea canephora) variety composites namely KR1-KR7 developed by NaCORI were used. The planting materials were cloned at the NaCORI. 


\section{Experimental Design}

Two spacing regimes were evaluated in a randomized complete block design with three replications at each of four sites during a second year of coffee growth, that is, from 12 to 21 months after planting. The spacing regimes include $3 \mathrm{~m} \times 1 \mathrm{~m}\left(3,333\right.$ coffee trees.ha $\left.{ }^{-1}\right)$ and $3 \mathrm{~m} \times 3 \mathrm{~m}\left(1,111\right.$ coffee trees.ha-1 $\left.{ }^{-1}\right)$. Rooted clonal cuttings at four pairs of leaf stage were planted into $60 \mathrm{~cm}$ x $60 \mathrm{~cm}$ holes dug some three weeks prior. Plot size was about $10 \mathrm{~m}$ x $10 \mathrm{~m}$; and each plot contained about 18 trees and 9 trees for $3 \mathrm{~m} \times 1 \mathrm{~m}$ and $3 \mathrm{~m} \times 3 \mathrm{~m}$ spacing regimes, respectively. During planting, each hole was covered with topsoil mixed with $10 \mathrm{~kg}$ of cowdung manure and supplemented with $50 \mathrm{~g}$ of diammonium phosphate fertilizer per hole. Medium term shade source (East African Highland banana cultivar Mbwazirume) and a long-term shade tree species Albizia coriaria were also included on the day of coffee planting at a spacing of $6 \mathrm{~m} \times 6 \mathrm{~m}$ and $15 \mathrm{~m} \times 15 \mathrm{~m}$, respectively. One stem per tree (for $3 \mathrm{~m} \times 1 \mathrm{~m}$ ) and three stems per tree (for $3 \mathrm{~m} \times 3 \mathrm{~m}$ plots) were maintained after coffee training which was started at six months after planting. Weeds were managed by a sequential of hand hoeing and then ring weeding with slashing, and blanket application of manure $\left(10 \mathrm{~kg} \cdot \mathrm{tree}^{-1}\right)$ and inorganic fertilizer (50 $\mathrm{g}$ of N.P.K 25-5-5 per tree) once every six months.

\section{Data Collection}

Eleven growth variables were measured on a quarterly basis starting at 12 up to 21 months after planting. The variables include stem girth, number of internodes on stem, plant height, canopy height, canopy diameter, number of primaries, number of active bearing primaries, length of longest primary, number of internodes on primary, leaf blade length and leaf blade width. The measurements were made in reference to Ferrão et al. (2019); Njoroge et al. (1992); and Bote (2016). Eight individual trees per plot were selected and marked for repeated growth measurements. Each selected tree was an observational unit. For plots containing $3 \mathrm{~m} \times 3 \mathrm{~m}$ spacing regimes and multiple stems per plant, a single most vigorous stem was tagged for observation.

Data on incidence of coffee pests was also recorded following 3 months intervals as for the growth parameters. Incidence of black coffee twig borer, leaf eating beetles, leaf miners, skeletonizers, and tailed caterpillars were measured per tree basing on sampling procedures described in Bukomeko et al. (2018) and Kagezi et al. (2015a).

\section{Statistical Analysis}

At each location, a first analysis of variance (ANOVA) model was analyzed:

$$
y_{i j k}=+R_{i}+A_{j}+S_{k}+A * S_{j k}+\varepsilon_{i j k}
$$

where $y_{i j k}$ is any observed growth response or pest incidence influenced by $i^{\text {th }}$ replication $(R), f^{\text {th }}$ age $(A)$ of coffee trees, $k^{\text {th }}$ spacing regime $(S), j k^{\text {th }}$ age by spacing regime $(A * S)$ interaction and $i j k^{\text {th }}$ random error ([). A Bonferroni test was then performed for mean separation between spacing regimes and across plant age. After accounting for replication (block) effects, locations means were pooled in spreadsheets with sources of variation as location (L), age within location (L(A)), spacing regime (S), location by spacing regime ( $\mathrm{L} \times \mathrm{S}$ ) and random error ([). The second ANOVA model analyzed was thus:

$$
y_{\mathrm{ijk}}=+L_{i}+L(A)_{j}+S_{k}+L * S_{j k}+\varepsilon_{i j k}
$$

where is any observed growth response or pest incidence as influenced by the sources of variation. Across location means were separated using least significant differences (1.s.d) for $\mathrm{L} x \mathrm{~S}$ interactions. In each test, significance was declared at $p<0.05$. age.

Growth response consistency was decided using the first ANOVA model (location specific 
ANOVA), particularly the age $\mathrm{x}$ spase component. Non-significance of age $x$ spase interaction was considered as consistence in growth response under a spacing regime irrespective of plant. Growth variables exhibiting significant $(p<0.05)$ age $x$ spase interaction indicated change in rank as coffee plants age and such variables were considered inconsistent.

Each of growth variables was assessed for existence of linear pattern with each of pest incidences. A Pearson's correlation coefficient (r) was used. Variable pairs with an absolute value of $r$ of at least 0.50 were progressed for linear regression analysis for which coefficients of determination $\left(\mathrm{R}^{2}\right)$ were applied. Where linear regression returned $\mathrm{R}^{2}$ $<0.50$ (less than $50 \%$ of variation explained), further iterations were performed using Pivot Chart in spreadsheets by exploring non-linear relationships namely exponential, logarithmic, polynomial, and power.

\section{RESULTS AND DISCUSSION}

\section{Growth Response}

Highly significant differences $(\mathrm{p}<0.01)$ between spacing regimes for most of measured growth variables were obtained (Table 1) at majority of locations. Overall, higher growth response was observed for $3 \mathrm{~m} \mathrm{x}$ $1 \mathrm{~m}$ than $3 \mathrm{~m} \times 3 \mathrm{~m}$. For instance, in Kituza at 21 MAP (months after planting), stem girth was $3.52 \mathrm{~cm}$ and $2.56 \mathrm{~cm}$ (Table 2); number of primaries was about 38 and 28 primaries for $3 \mathrm{~m} \mathrm{x} 1 \mathrm{~m}$ and $3 \mathrm{~m} \times 3 \mathrm{~m}$, respectively. In Kyotera at 18 months after planting, stem girth was $1.68 \mathrm{~cm}$ and $1.10 \mathrm{~cm}$; number of primaries was about 18 and 13 for $3 \mathrm{~m}$ $\mathrm{x} 1 \mathrm{~m}$ and $3 \mathrm{~m} \times 3 \mathrm{~m}$, respectively. The results obtained in Mitooma and Mukono were like those in Kituza and Kyotera.

Across locations, highly significant differences $(p<0.01)$ between spacing regimes were obtained (Table 3) for stem girth, number of internodes on stem, plant height, canopy height, canopy diameter, number of primaries, length of longest primary, and number of internodes on primary but not for number of active bearing primaries, leaf blade length, and leaf blade width $(\mathrm{p}>0.01)$. For all growth variables, higher mean values were obtained under $3 \mathrm{mx} 1 \mathrm{~m}$ than with $3 \mathrm{mx} 3 \mathrm{~m}$ (Table 4). The mean stem girth was $2.06 \mathrm{~cm}$ and $1.72 \mathrm{~cm}$ for $3 \mathrm{~m} \mathrm{x} 1 \mathrm{~m}$ and $3 \mathrm{~m} \mathrm{x} 3 \mathrm{~m}$; number of primaries was about 21 and 17 for $3 \mathrm{~m} \mathrm{x} 1 \mathrm{~m}$ and $3 \mathrm{~m} \times 3 \mathrm{~m}$, respectively.

Better early-stage growth response under high plant densities than low densities is attributable to high level of fertilizer inputs per unit area (Al-Naggar et al., 2015; Pereira et al., 2013; Sseremba et al., 2021; Ullasa et al., 2014). Clearly, the usual practice is to apply the manures and fertilizers on each tree, making it a three-fold rate per unit area for the case of tripled densities. Where organic manures are applied (as was the case is this study), soil health including water retention capacity (Ashine, 2019; De Pascale et al., 2011; Njoroge et al., 1992; Tesfaye et al., 2013) receives a tripod-scale improvement under $3 \mathrm{~m} \mathrm{x} 1 \mathrm{~m}$ relative to $3 \mathrm{~m} \times 3 \mathrm{~m}$. The observations also implicate a probable area of investigation of whether $C$. canephora plants known for their preference to shaded systems can exploit close spacing to intensify inter-plant hormonal communication for selfshading. A longitudinal follow up on costbenefit evaluation for cost justification of tripled input requirements in $3 \mathrm{~m} \times 1 \mathrm{~m}$ spaced coffee plantations (based on treelevel application tendency) is another area for future clarification.

\section{Growth Response Consistency}

Within locations, coffee tree age $\mathrm{x}$ spacing regime interactions were non-significant $(p>0.05)$ for some variables in most of the 
Sseremba et al.

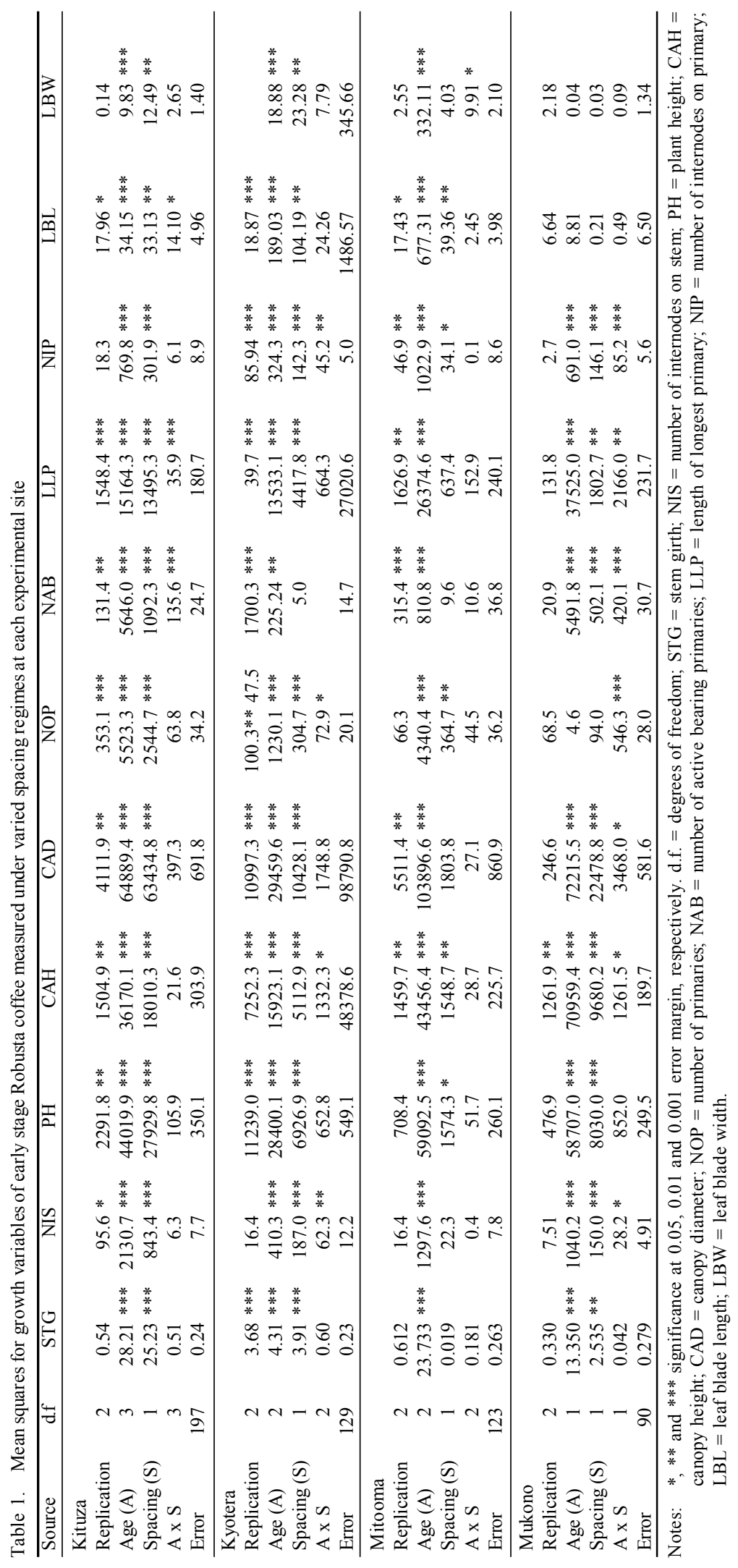




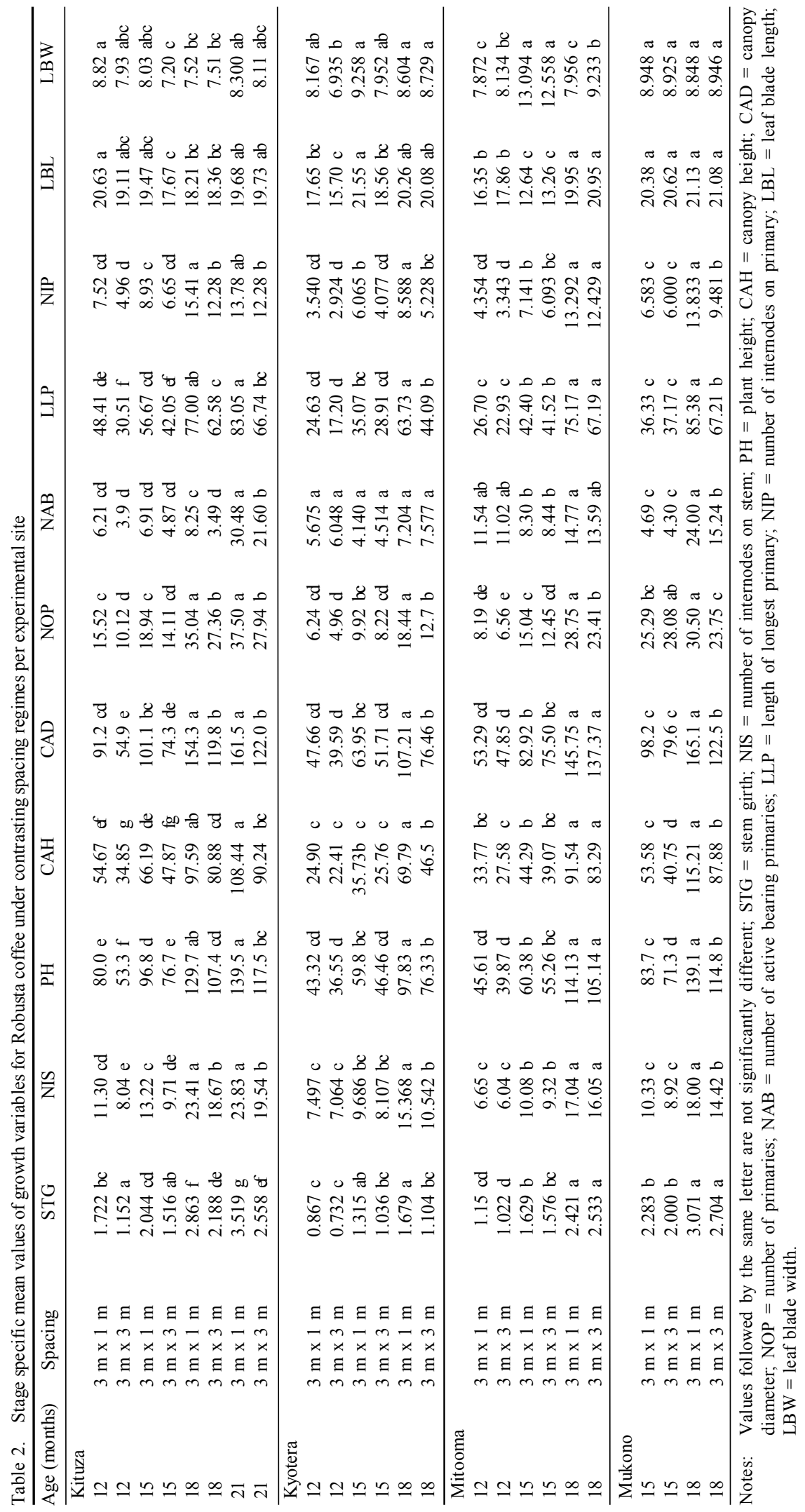


Sseremba et al.

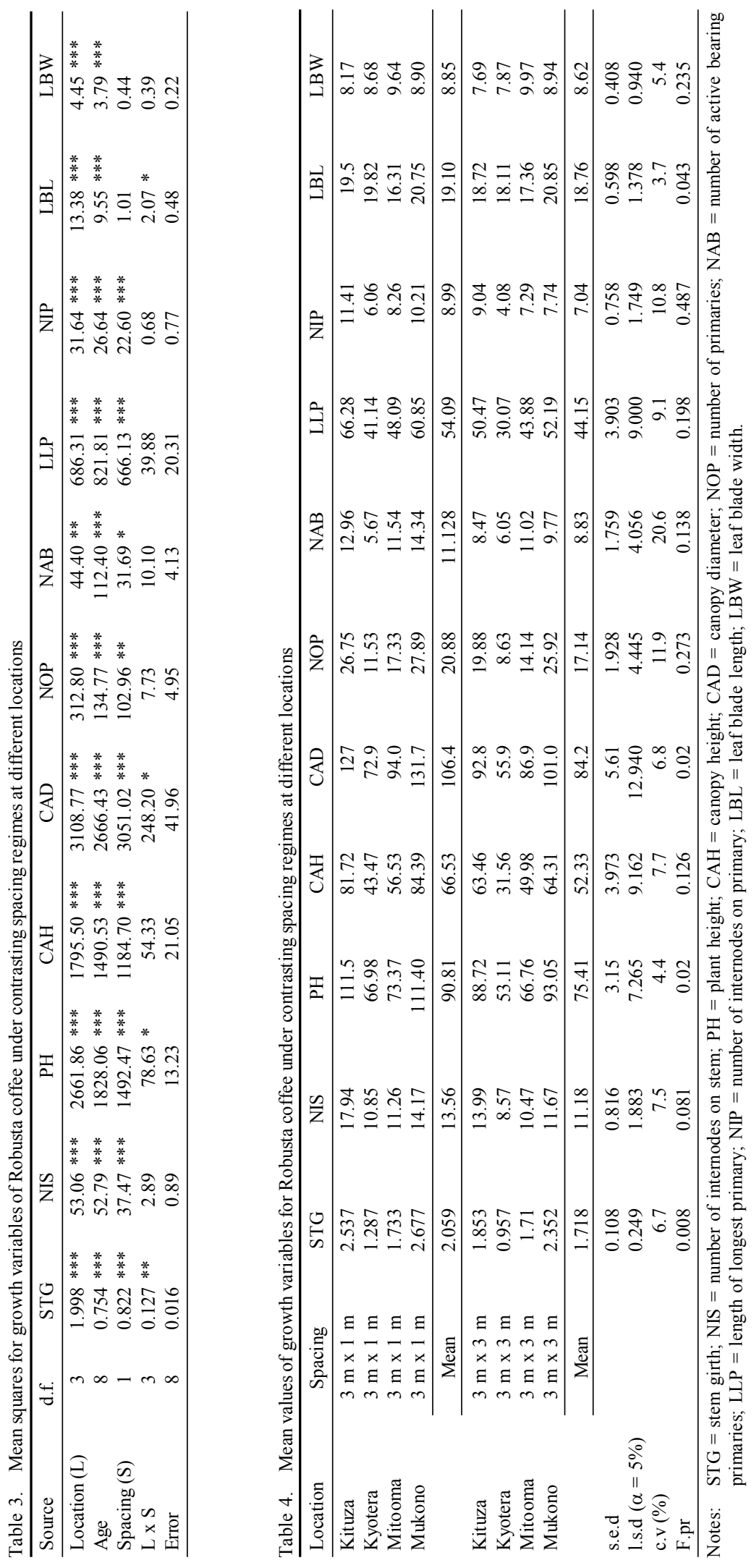


locations. In Kituza, significant ( $\mathrm{p}>0.05)$ age $\mathrm{x}$ spase interactions were obtained for number of active bearing primaries, length of longest primary and leaf blade length. Non-significant age $\mathrm{x}$ spase interactions in Kyotera were obtained for stem girth, plant height, canopy diameter, length of longest primary, leaf blade length and leaf blade width. Leaf blade width exhibited significant age $\mathrm{x}$ spase interactions in Mitooma. In Mukono, non-significant age $\mathrm{x}$ spase interactions were obtained for stem girth, plant height, leaf blade length and leaf blade width. Thus far, stem girth and plant height per spacing regime did not change in rank as tree age varied.

Across locations, location $x$ spacing (L $x S)$ interactions were $(p>0.05)$ significant for stem girth, plant height, canopy diameter and leaf blade length. Among the location stable growth variables, the following correlations were obtained: number of internodes on stem and canopy height, $\mathrm{R}^{2}=86 \%$; number of internodes on stem and number of primaries, $\mathrm{R}^{2}=72 \%$; number of internodes on stem and length of longest primary, $\mathrm{R}^{2}=86 \%$; number of internodes on stem and number of internodes on primary, $\mathrm{R}^{2}=94 \%$ (Table 9 ). Very weak correlation between number of internodes on stem and leaf blade width $\left(\mathrm{R}^{2}\right.$ $=1 \%$ ) was obtained.

To reach fair recommendations about suitable spacing regimes, a few consistent morphological measurements are ideal especially for large experiments. Stem girth and plant height are deemed good growth response parameters on account of their stability across replications for specific spacing regimes within test sites. When stem girth was higher under $3 \mathrm{mx} 3 \mathrm{~m}$ in the first replication; the ranking remained unchanged for second and third replications. More importantly, across location consistency of ranking in plant growth was achieved for some parameters. The across location stable growth response variables were number of internodes on stem, canopy height, number of primaries, number of active bearing primaries, length of longest primary, number of internodes on primary and leaf blade width. The number of these variables could be trimmed further by dealing with redundancy for strongly correlated traits. As such, the following trait pairs with coefficients of determination $\left(\mathrm{R}^{2}\right)$ of over $70 \%$ provide options for trimming: number of internodes on stem and canopy height, number of internodes on stem and number of primaries, number of internodes on stem and length of longest primary, number of internodes on stem and number of internodes on primary. Our experience vindicates length of longest primary as involving less drudgery during data collection than the rest of correlated traits (Sseremba et al., 2021). An accumulative account suggests that stem girth, plant height, length of longest primary, and leaf blade width are the most stable and hence suitable for delineating the effect of plant population on growth response in early-stage C. canephora.

\section{Spacing Regime Effect}

Spacing regimes differed significantly for incidence of some pests in specific locations (Table 5). Incidence of black coffee twig borer was significantly different in Kituza $(\mathrm{p}<0.05)$ and Kyotera $(\mathrm{p}<0.001)$ but non-significant in Mitooma and Mukono. At 18 months after planting, black coffee twig borer incidence was higher (about 9.0\%) under $3 \mathrm{~m} \mathrm{x} 1 \mathrm{~m}$ than with $3 \mathrm{~m} \mathrm{x} 3 \mathrm{~m}$ $(5.0 \%)$; quite similar trend was obtained in Mukono (Table 6). Incidence of leaf eating beetles was significantly different in Kyotera and Mitooma $(\mathrm{p}<0.05)$ but non-significant in Kituza and Mukono. Very highly significant differences $(p<0.001)$ between spacing regimes were obtained for leaf miners in Kituza but non-significant ( $\mathrm{p}>0.05)$ for rest of locations. Incidence of skeletonizers was 
Sseremba et al.

Table 5. Mean squares for pest incidence in early stage Robusta coffee measured under varied spacing regimes at each experimental site
Table 5. Mean squares for pest incidence in early stage Robusta coffee measured under varied spacing regimes at each expetimental

\begin{tabular}{|c|c|c|c|c|c|c|}
\hline Source & d.f & ВCTB & LEB & LM & SKL & $\mathrm{TC}$ \\
\hline \multicolumn{7}{|l|}{ Kituza } \\
\hline Replication & 2 & 25.6 & $822.0 * *$ & 51.57 & $754.7 * * *$ & $701.4 * *$ \\
\hline Age (A) & 2 & $128.2 * *$ & $780.3 * *$ & $56.9 *$ & 302.5 & $6375.2 * * *$ \\
\hline Spacing (S) & 1 & $94.2 *$ & 286.9 & $259.9 * * *$ & 304.1 & $1496.8 * * *$ \\
\hline$A \times S$ & 2 & 23.9 & 16.0 & 2.36 & 23.1 & 221.8 \\
\hline Error & 143 & 19.7 & 138.8 & 18.19 & 108 & 138.7 \\
\hline \multicolumn{7}{|l|}{ Kyotera } \\
\hline Replication & 2 & 122.3 & 105.9 & 201.2 & $749.1 *$ & $3351.0 * * *$ \\
\hline Age (A) & 2 & $300.3 *$ & $2962.0 * * *$ & $1162.9 * *$ & $2643.5 * * *$ & $8124.1 * * *$ \\
\hline Spacing (S) & 1 & $942.3 * * *$ & $574.3 *$ & 124.2 & 34.9 & $1357.7 *$ \\
\hline$A \times S$ & 2 & 70.6 & 139.5 & 127.1 & 17.5 & 169.5 \\
\hline Error & 109 & 78.0 & 128.8 & 169.6 & 211.5 & 342.0 \\
\hline \multicolumn{7}{|l|}{ Mitooma } \\
\hline Replication & 2 & 0.0 & 100.9 & 54.8 & $345.3 *$ & 253.5 \\
\hline Age (A) & 2 & 0.0 & $1678.4 * * *$ & $487.4 * * *$ & 49.9 & $12315.8 * * *$ \\
\hline Spacing (S) & 1 & 0.0 & $484.7 *$ & 135.7 & $987.3 * * *$ & 439.3 \\
\hline$A \times S$ & 2 & 0.0 & 63.3 & 52.7 & 111.2 & $1093.3 * *$ \\
\hline Error & 119 & 0.0 & 99.9 & 45.7 & 84.4 & 224.8 \\
\hline \multicolumn{7}{|l|}{ Mukono } \\
\hline Replication & 2 & $339.7 * *$ & 112.0 & 65.3 & 50.4 & 52.6 \\
\hline Age (A) & 1 & $5121.9 * * *$ & $553.9 * *$ & $273.0 *$ & $6073.3 * * *$ & $15448.9 * * *$ \\
\hline Spacing (S) & 1 & 33.1 & 189.1 & 68.1 & $752.6 *$ & 47.4 \\
\hline$A \times S$ & 1 & 28.4 & 98.9 & 12.3 & 28.0 & $1783.3^{* *}$ \\
\hline Error & 90 & 67.1 & 80.1 & 59.0 & 142.9 & 244.7 \\
\hline
\end{tabular}

Table 6. Stage specific mean values of pest incidence in Robusta coffee under contrasting spacing regimes per experimental

\begin{tabular}{|c|c|c|c|c|c|c|}
\hline Age (months) & Spacing & ВСТВ & LEB & LM & SKL & $\mathrm{TC}$ \\
\hline \multicolumn{7}{|l|}{ Kituza } \\
\hline 12 & $3 \mathrm{~m} \times 1 \mathrm{~m}$ & $0.0 \mathrm{a}$ & $5.5 \mathrm{a}$ & $4.3 \mathrm{ab}$ & $3.5 \mathrm{a}$ & $17.9 \mathrm{~b}$ \\
\hline 12 & $3 \mathrm{~m} \times 3 \mathrm{~m}$ & $0.0 \mathrm{a}$ & $9.4 \mathrm{a}$ & $2.2 \mathrm{a}$ & $7.8 \mathrm{a}$ & $13.4 \mathrm{~b}$ \\
\hline 15 & $3 \mathrm{mx} 1 \mathrm{~m}$ & $1.5 \mathrm{ab}$ & $13.0 \mathrm{a}$ & $6.4 \mathrm{~b}$ & $8.8 \mathrm{a}$ & $31.1 \mathrm{c}$ \\
\hline 15 & $3 \mathrm{~m} \times 3 \mathrm{~m}$ & $3.8 \mathrm{~b}$ & $15.1 \mathrm{a}$ & $3.7 \mathrm{ab}$ & $10.8 \mathrm{a}$ & $28.0 \mathrm{c}$ \\
\hline 18 & $3 \mathrm{~m} \times 1 \mathrm{~m}$ & $1.5 \mathrm{ab}$ & $13.0 \mathrm{a}$ & $6.4 \mathrm{~b}$ & $8.8 \mathrm{a}$ & $13.5 \mathrm{~b}$ \\
\hline 18 & $3 \mathrm{~m} \times 3 \mathrm{~m}$ & $3.8 \mathrm{~b}$ & $15.1 \mathrm{a}$ & $3.7 \mathrm{ab}$ & $10.8 \mathrm{a}$ & $2.8 \mathrm{a}$ \\
\hline \multicolumn{7}{|l|}{ Kyotera } \\
\hline 12 & $3 \mathrm{~m} \times 1 \mathrm{~m}$ & $3.9 a b c$ & $3.2 \mathrm{a}$ & $8.2 \mathrm{ab}$ & $13.8 \mathrm{abc}$ & $20.4 \mathrm{a}$ \\
\hline 12 & $3 \mathrm{~m} \times 3 \mathrm{~m}$ & $0.2 \mathrm{ab}$ & $8.5 \mathrm{a}$ & $9.5 \mathrm{ab}$ & $13.4 \mathrm{abc}$ & $17.5 \mathrm{a}$ \\
\hline 15 & $3 \mathrm{~m} \times 1 \mathrm{~m}$ & $7.6 \mathrm{bc}$ & $2.8 \mathrm{a}$ & $7.0 \mathrm{a}$ & $24.1 \mathrm{bc}$ & $25.9 \mathrm{a}$ \\
\hline 15 & $3 \mathrm{~m} \times 3 \mathrm{~m}$ & $0.0 \mathrm{a}$ & $9.4 \mathrm{a}$ & $5.9 \mathrm{a}$ & $26.1 \mathrm{c}$ & $20.7 \mathrm{ab}$ \\
\hline 18 & $3 \mathrm{mx} 1 \mathrm{~m}$ & $8.8 \mathrm{c}$ & $19.5 \mathrm{~b}$ & $13.3 \mathrm{ab}$ & $10.5 \mathrm{a}$ & $48.5 \mathrm{a}$ \\
\hline 18 & $3 \mathrm{~m} \times 3 \mathrm{~m}$ & $5.0 a b c$ & $19.6 \mathrm{~b}$ & $18.6 \mathrm{~b}$ & $11.9 a b$ & $38.2 \mathrm{c}$ \\
\hline \multicolumn{7}{|l|}{ Mitooma } \\
\hline 12 & $3 \mathrm{~m} \times 1 \mathrm{~m}$ & $0.0 \mathrm{a}$ & $2.2 \mathrm{a}$ & $2.6 \mathrm{ab}$ & $8.8 \mathrm{ab}$ & $16.2 \mathrm{a}$ \\
\hline 12 & $3 \mathrm{~m} \times 3 \mathrm{~m}$ & $0.0 \mathrm{a}$ & $6.0 \mathrm{a}$ & $2.1 \mathrm{a}$ & $10.6 a b$ & $12.4 \mathrm{a}$ \\
\hline 15 & $3 \mathrm{~m} \times 1 \mathrm{~m}$ & $0.0 \mathrm{a}$ & $1.9 \mathrm{a}$ & $7.6 \mathrm{abc}$ & $4.2 \mathrm{a}$ & $5.3 \mathrm{a}$ \\
\hline 15 & $3 \mathrm{~m} \times 3 \mathrm{~m}$ & $0.0 \mathrm{a}$ & $3.2 \mathrm{a}$ & $3.2 \mathrm{ab}$ & $11.5 \mathrm{ab}$ & $5.3 \mathrm{a}$ \\
\hline 18 & $3 \mathrm{mx} 1 \mathrm{~m}$ & $0.0 \mathrm{a}$ & $10.6 \mathrm{ab}$ & $9.2 \mathrm{c}$ & $6.1 \mathrm{ab}$ & $29.3 \mathrm{~b}$ \\
\hline 18 & $3 \mathrm{~m} \times 3 \mathrm{~m}$ & $0.0 \mathrm{a}$ & $16.4 \mathrm{~b}$ & $8.218 \mathrm{bc}$ & $12.7 \mathrm{~b}$ & $43.6 \mathrm{c}$ \\
\hline \multicolumn{7}{|l|}{ Mukono } \\
\hline 15 & $3 \mathrm{~m} \times 1 \mathrm{~m}$ & $2.3 \mathrm{a}$ & $5.4 \mathrm{ab}$ & $1.4 \mathrm{a}$ & $11.8 \mathrm{a}$ & $18.8 \mathrm{a}$ \\
\hline 15 & $3 \mathrm{~m} \times 3 \mathrm{~m}$ & $0.0 \mathrm{a}$ & $10.2 \mathrm{~b}$ & $3.8 \mathrm{a}$ & $16.3 \mathrm{a}$ & $11.6 \mathrm{a}$ \\
\hline 18 & $3 \mathrm{~m} \times 1 \mathrm{~m}$ & $15.8 \mathrm{~b}$ & $2.6 \mathrm{a}$ & $5.5 \mathrm{a}$ & $26.6 \mathrm{~b}$ & $35.5 \mathrm{~b}$ \\
\hline 18 & $3 \mathrm{~m} \times 3 \mathrm{~m}$ & $15.7 \mathrm{~b}$ & $3.4 \mathrm{ab}$ & $6.4 \mathrm{a}$ & $33.3 \mathrm{~b}$ & $45.6 \mathrm{~b}$ \\
\hline
\end{tabular}


very highly significantly different $(\mathrm{p}<0.001)$ in Mitooma, significant $(p<0.05)$ in Mukono but non-significant in other test locations. Very highly significant differences $(\mathrm{p}<0.001)$ between spacing regimes were obtained for tailed caterpillars in Kituza, significant $(\mathrm{p}<0.05)$ in Kyotera and non-significant for rest of locations.

Across locations, spacing regimes significantly differed $(p<0.05)$ for incidence of black coffee twig borer, leaf eating beetles, and skeletonizers (Table 7) but did not differ $(p>0.05)$ for leaf miners and tailed caterpillars. The incidences of black coffee twig borer, leaf miners and tailed caterpillars were higher under $3 \mathrm{~m} \times 1 \mathrm{~m}$ (black coffee twig borer, $4.2 \%$; leaf miners, $6.3 \%$; tailed caterpillars, $24.1 \%$ ) than with $3 \mathrm{~m} \times 3 \mathrm{~m}$ (black coffee twig borer, $3.1 \%$; leaf miners, $6.0 \%$; tailed caterpillars, 22.3\%) (Table 8). Conversely, incidences for leaf eating beetles and skeletonizers were lower under $3 \mathrm{~m} \mathrm{x} 1 \mathrm{~m}$ (leaf eating beetles, $7.0 \%$; skeletonizers, $12.2 \%$ ) than with $3 \mathrm{~m} \times 3 \mathrm{~m}$ (leaf eating beetles, $10.3 \%$; skeletonizers, $15.8 \%$ ).
Consistent with Bukomeko et al. (2018) and Kagezi et al. (2013), differences in microenvironments brought about by level of shading intensity influence pest incidence. A matching context is with ambrosia beetles some of whose members enjoy a symbiotic relationship with fungi (Kagezi et al., 2015b). Most fungi proliferate asexually under moist conditions of shaded or high plant density in the tropics (Dobo et al., 2018; Kagezi et al., $2015 b$ ) thereby providing food for opportunistic pests like the black coffee twig borer (Kagezi et al., 2014; Wu, 2016). Short-range flying pests such as black coffee twig borer characterized by localized infestation patterns are further facilitated to spread from one plant to another close by plant in dense ( $3 \mathrm{~m}$ $\mathrm{x} 1 \mathrm{~m})$ spacing regimes. The argument of plant-plant proximity for fast pest and disease spread is also held by Biruk (2018). For Kagezi et al. (2013) and Bukomeko et al. (2018), shading in C. canephora was reportedly occasioned by non-coffee species such as banana (Musa spp), Albizia chinensis, Ficus spp, A. coriaria, Maeopsis spp and

Table 7. Mean squares of pest incidence in Robusta coffee under contrasting spacing regimes at different locations

\begin{tabular}{lcccccc}
\hline Source & d.f & BCTB & LEB & LM & SKL & TC \\
\hline Location (L) & 3 & $63.21 * * *$ & $48.68 * *$ & $47.41 * *$ & $207.66 * * *$ & $184.30 *$ \\
Age & 7 & $35.38^{* * *}$ & $66.82 * * *$ & $21.87 * *$ & $71.39 * * *$ & $402.77 * * *$ \\
Spacing (S) & 1 & $7.49 *$ & $60.83 * *$ & 0.91 & $65.92 * * *$ & 24.80 \\
L x S & 3 & $11.74 * *$ & 0.59 & 7.47 & 6.43 & 35.78 \\
Error & 7 & 1.15 & 3.17 & 2.24 & 1.94 & 27.99 \\
\hline
\end{tabular}

Table 8. Mean values of pest incidence in Robusta coffee under contrasting spacing regimes at different locations

\begin{tabular}{|c|c|c|c|c|c|c|}
\hline Location & Spacing & $\mathrm{BCTB}$ & LEB & LM & SKL & $\mathrm{TC}$ \\
\hline Kituza & $3 \mathrm{~m} \times 1 \mathrm{~m}$ & 1.0 & 10.5 & 5.7 & 7.0 & 20.8 \\
\hline Kyotera & $3 \mathrm{~m} \times 1 \mathrm{~m}$ & 6.8 & 8.5 & 9.5 & 16.1 & 31.6 \\
\hline Mitooma & $3 \mathrm{~m} \times 1 \mathrm{~m}$ & 0.0 & 4.9 & 6.5 & 6.3 & 16.9 \\
\hline \multirow[t]{2}{*}{ Mukono } & $3 \mathrm{~m} \mathrm{x} 1 \mathrm{~m}$ & 9.0 & 4.0 & 3.4 & 19.2 & 27.2 \\
\hline & Mean & 4.2 & 7.0 & 6.3 & 12.2 & 24.1 \\
\hline Kituza & $3 \mathrm{~m} \times 3 \mathrm{~m}$ & 2.6 & 13.2 & 3.2 & 9.8 & 14.7 \\
\hline Kyotera & $3 \mathrm{~m} \times 3 \mathrm{~m}$ & 1.8 & 12.5 & 11.3 & 17.1 & 25.5 \\
\hline Mitooma & $3 \mathrm{~m} \times 3 \mathrm{~m}$ & 0.0 & 8.5 & 4.5 & 11.6 & 20.4 \\
\hline \multirow[t]{2}{*}{ Mukono } & $3 \mathrm{~m} \times 3 \mathrm{~m}$ & 7.8 & 6.8 & 5.1 & 24.8 & 28.6 \\
\hline & Mean & 3.1 & 10.3 & 6.0 & 15.8 & 22.3 \\
\hline s.e.d & & 0.980 & 1.630 & 1.360 & 1.270 & 4.830 \\
\hline l.s.d $(\alpha=5 \%)$ & & 2.320 & 3.840 & 3.230 & 3.010 & 11.420 \\
\hline c.v $(\%)$ & & 33.7 & 20.0 & 23.6 & 10.5 & 23.2 \\
\hline F.pr & & 0.006 & 0.902 & 0.086 & 0.087 & 0.354 \\
\hline
\end{tabular}


various fruit trees (like Avocado and jackfruit). Variation in coffee plant density does create shade even though the quality of resulting microenvironments differs from that of non-coffee species. In our study, Musa spp was included at a uniform rate throughout experimental locations. For most pests, incidence was higher under high plant density $(3 \mathrm{~m} \times 1 \mathrm{~m})$ than low density by first two years of $C$. canephora growth but follow up longitudinal studies with additional factors like stem number and fertilizer rate are necessary for enabling holistic recommendations.

\section{Growth and Pest Incidences Correlation}

Incidence of black coffee twig borer was moderately linearly correlated with canopy height, leaf blade length, length of longest primary, number of active bearing primaries and plant height $(r>0.50, \mathrm{p}<0.001$, $\mathrm{R}^{2}>0.25$ ) (Table 9). Under $3 \mathrm{~m} \times 1 \mathrm{~m}$ and $3 \mathrm{~m} \times 3 \mathrm{~m}$ spacing regimes, the incidence of black coffee twig borer was predictable by canopy height in a polynomial relationship with coefficients of determination $\left(\mathrm{R}^{2}\right)$ of up to 0.86 and 0.90 , respectively. Though the polynomial relationship had the highest $\mathrm{R}^{2}$, a clearer trend but with reduced value of $\mathrm{R}^{2}$ was observed with logarithmic relationships (Figure 1). The relationship of black coffee twig borer incidence with number of active bearing primaries was also polynomial at $\mathrm{R}^{2}$ of up to 0.81 and 0.94 under $3 \mathrm{~m} \times 1 \mathrm{~m}$ and $3 \mathrm{~m} \times 3 \mathrm{~m}$, respectively. Though the polynomial relationship had the highest $\mathrm{R}^{2}$, a clearer trend but with reduced value of $\mathrm{R}^{2}$ was observed with linear relationships (Figure 2). Incidence of was moderate to strongly linearly correlated with leaf blade length $\left(r=0.62, p<0.001, R^{2}=0.38\right)$. Power and polynomial relationships of incidence with leaf blade length were obtained with $\mathrm{R}^{2}=0.65$ and $\mathrm{R}^{2}=0.74$ under $3 \mathrm{~m} \times 1 \mathrm{~m}$ and $3 \mathrm{~m} \times 3 \mathrm{~m}$, respectively. Though the polynomial

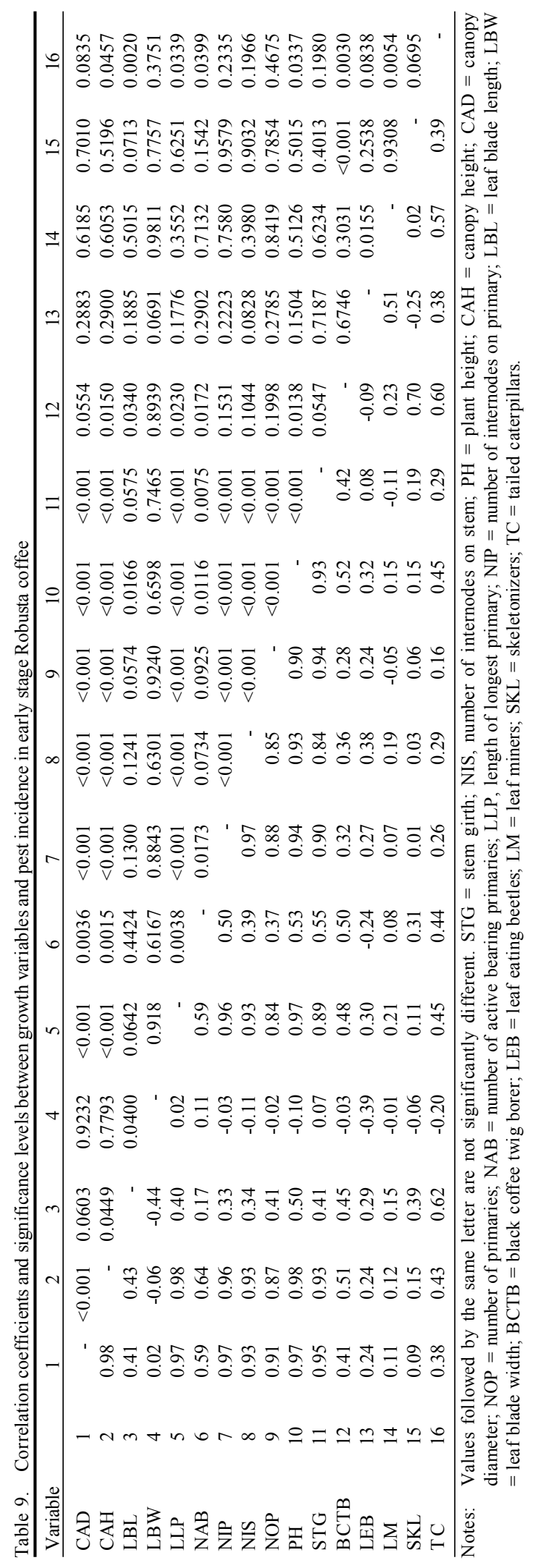




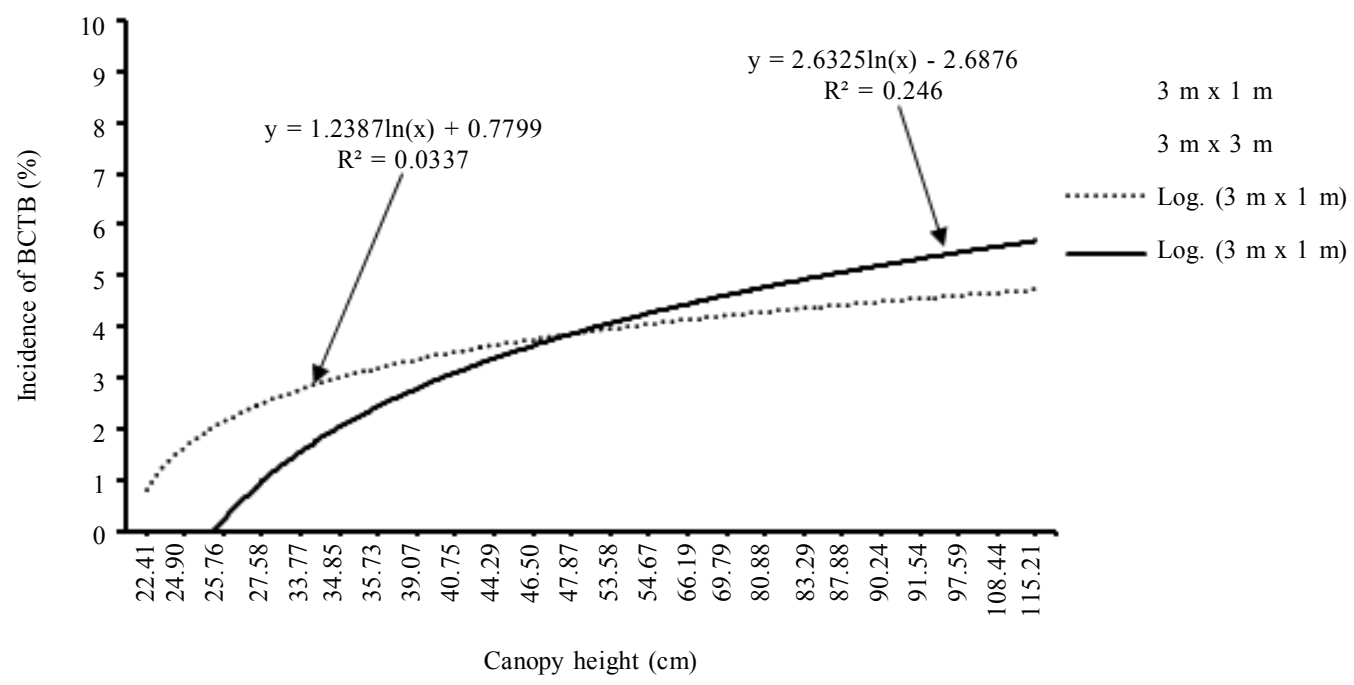

Figure 1. Relationship between incidence of black coffee twig borer (BCTB) and canopy height under two contrasting spacing regimes

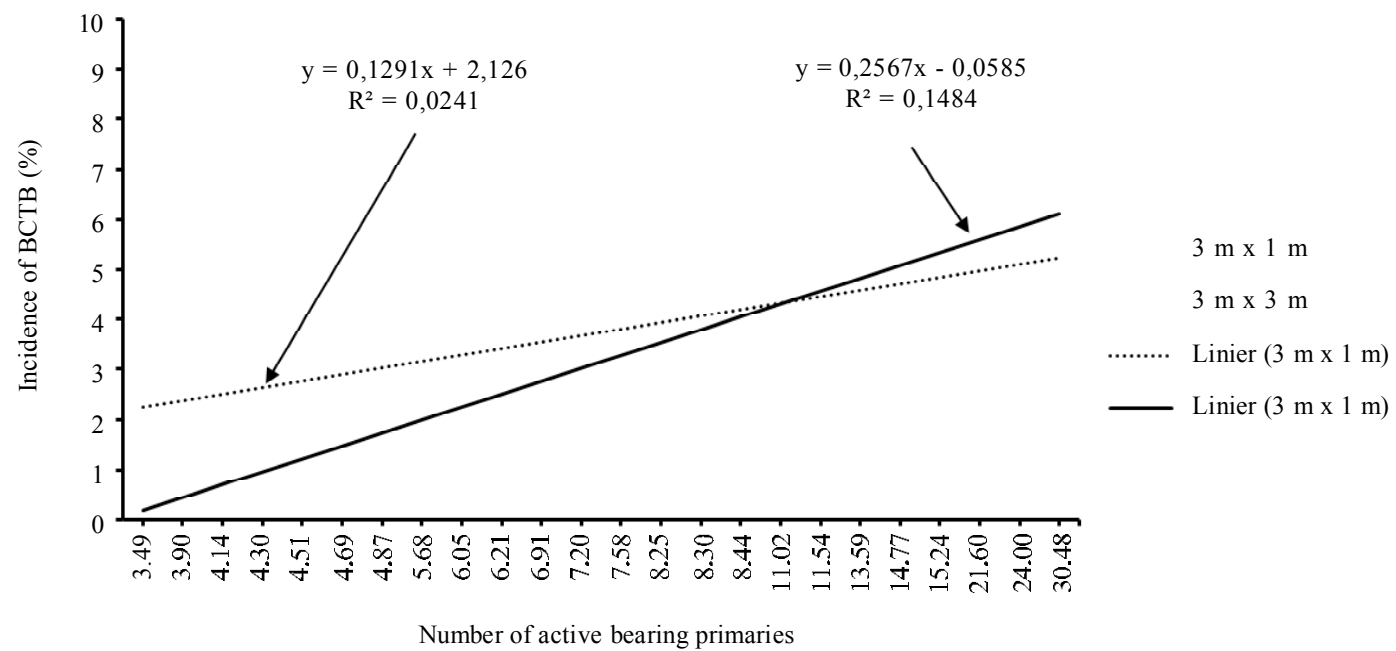

Figure 2. Relationship between incidence of black coffee twig borer (BCTB) and number of active bearing primaries under two contrasting spacing regimes 


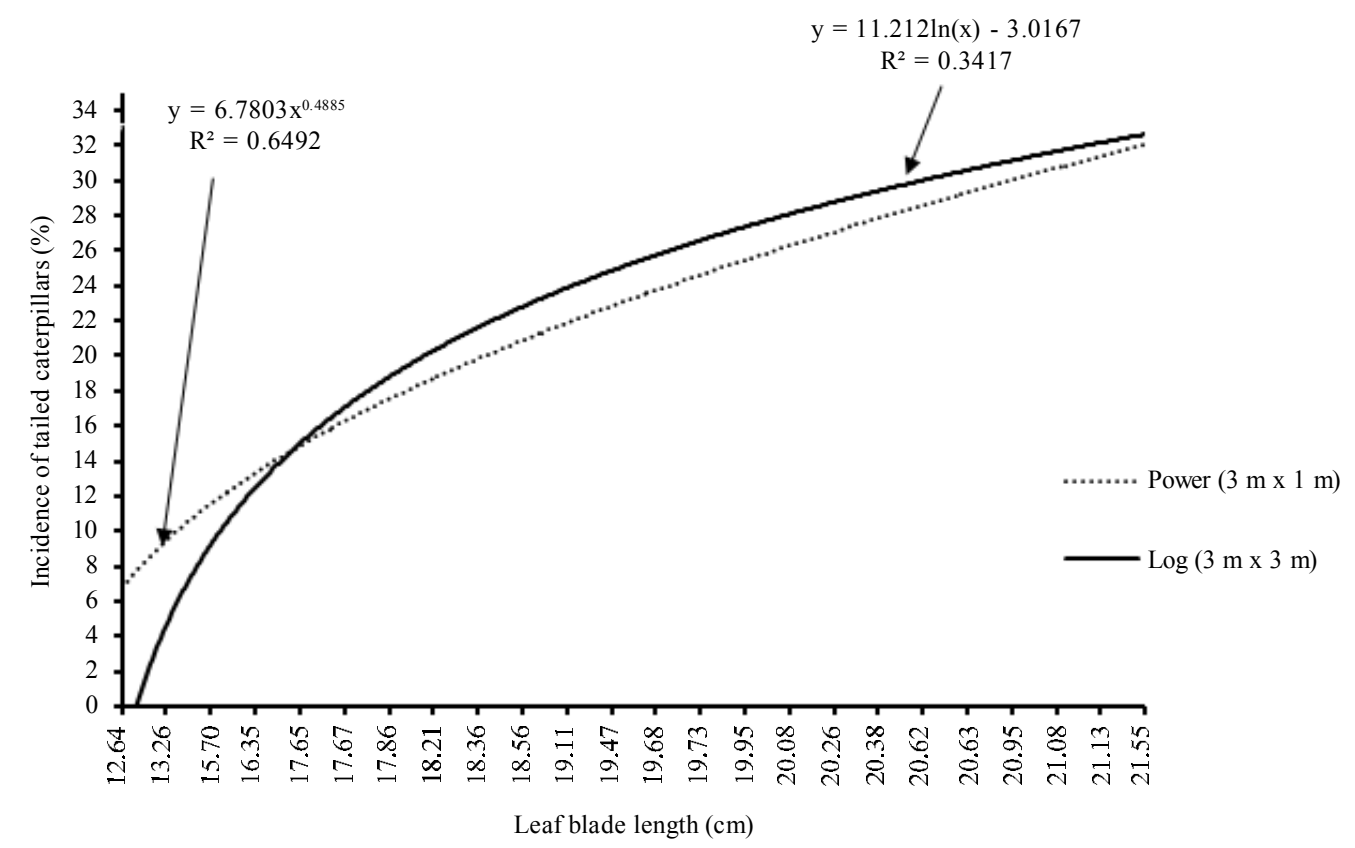

Figure 3. Relationship between incidence of tailed caterpillars (TC) and leaf blade length (LBL)

relationship had the highest $\mathrm{R}^{2}$, a clearer trend but with reduced value of $\mathrm{R}^{2}$ was observed with power and logarithmic relationships (Figure 3). Strong linear correlation was also observed between incidences of some pest pairs, particularly, leaf miners with leaf eating beetles $(\mathrm{r}=0.51, \mathrm{p}<0.001)$, black coffee twig borer with skeletonizers $(r=0.70$, $\mathrm{p}<0.001, \mathrm{R}^{2}=0.49$ ), black coffee twig borer with tailed caterpillars $(r=0.60, p<0.001$, $\left.\mathrm{R}^{2}=0.36\right)$ and tailed caterpillars with leaf miners $\left(\mathrm{r}=0.57, \mathrm{p}<0.001, \mathrm{R}^{2}=0.32\right)$.

Positive moderate association between some pests and growth variables generally emphasizes the creation of suitable conditions that favor pest multiplication as plants grow. On a further probing by way of regression model options, it was established that nonlinear relationship of pest incidence with growth response accounted for most the variation. The incidence of black coffee twig borer suggested wavy peaks as coffee plants grew; and the peaks alternated for the two spacing regimes. When black coffee twig borer incidence under $3 \mathrm{~m} \times 1 \mathrm{~m}$ spacing was at maximum, that under $3 \mathrm{~m} \times 3 \mathrm{~m}$ was lowest; and this relationship continued in a wavy fashion to depict seasonal changes. The alternations in curves for the two spacing regimes indicate that at some point or season, conditions are conducive for pest proliferation for only one of the two spacing regimes. Pest and disease status is known to oscillate with weather conditions (Chemura, 2017; Kagezi et al., 2015a; Legg et al., 2011; Musoli et al., 2008). It can be argued that in the wet season, cold condition is unfavorable to pest development prevail under high plant density spacing regime; here the pest population drops (Bukomeko et al., 2018; Kagezi et al., 2015b, 2013; Sseremba et al., 2021). On the contrary, low plant density spacing regime during the wet season can allow better air movement and overall good conditions for pest survival, hence a high pest incidence. In the dry season, pest population dynamics differ in that highly shaded plantations for the case of high densities $(3 \mathrm{~m}$ $\mathrm{x} 1 \mathrm{~m}$ ) promotes humid conditions whereby 
favoring fungal growth (Egonyu et al., 2015a; Kagezi et al., 2014; Matovu et al., 2013). Fungal growth attracts some pests, such as black coffee twig borer (Bukomeko et al., 2018; Wu, 2016). Wide spacing in the dry season may lead to faster loss of moisture depending on soil type (Njoroge et al., 1992; Ullasa et al., 2014) and associated fungal symbionts with such pests as black coffee twig borer may not survive (Egonyu et al., 2015a, 2015b). When coffee plants reach bearing stages or as plants grow, dynamics of growth response and pest incidence are likely to change as plant nutrient demand and partitioning of photosynthates for bean development and biosynthesis of quality ingredients also varies; areas not enquired in this study.

\section{CONCLUSIONS}

Close spacing ( $3 \mathrm{~m} \times 1 \mathrm{~m})$ at pre-bearing stage produces better growth response than wide spacing $(3 \mathrm{~m} \times 3 \mathrm{~m})$. It implies that the first years of cropping cycles may yield better under high C. canephora tree density owing to non-limiting input per unit area than low density populations; even though supporting agronomic practices ought to be optimized. The variation in growth response between contrasting spacing regimes can reliably be followed using a few drudgery reducing parameters namely stem girth, plant height, length of longest primary and leaf blade width. Incidence of most pests namely black coffee twig borer, leaf eating beetles, leaf miners and tailed caterpillars was also higher under $3 \mathrm{mx} 1 \mathrm{~m}$ than $3 \mathrm{~m} \mathrm{x} 3 \mathrm{~m}$. However, incidence of skeletonizers was lower under high plant density than low plant populations. It is notable that pest incidence (Xylosandrus compactus in particular) exhibited interactions of location (environment) and spacing regime. Non-linear positive relationships between growth response and pest incidence were also established, indicating that pest problems increase with plant age in C. canephora. The scenario of increase in pest incidence with coffee tree growth response is worse under high densities than low plant populations.

\section{ACKNOWLEDGEMENT}

This study was funded by Uganda Coffee Development Authority (UCDA).

\section{REFERENCES}

Al-Naggar, A.M.M.; R.A. Shabana; M.M. Atta \& T.H. Al-Khalil (2015). Maize response to elevated plant density combined with lowered N-fertilizer rate is genotypedependent. The Crop Journal, 3, 96-109.

Aluka (2013). Genetic and Phenotypic Diversity of Cultivated Robusta Roffee (Coffea canephora Pierre) in Uganda and Effect of Environmental Factors on Quality. $\mathrm{PhD}$ Thesis. University of Nairobi, Kenya.

Ashine, E.T. (2019). Determination of crop water requirement and irrigation water requirement for coffee arabica (Coffea Arabica L.): Case study of Somodo Watershed. International Journal of Research Studies in Agricultural Sciences, 5, 1-8.

Biruk, A. (2018). Impact of shade on morphophysiological characteristics of coffee plants, their pests and diseases: A review. African Journal of Agricultural Research, 13, 2016-2024.

Boreux, V.; P. Vaast; L.P. Madappa; K.G. Cheppudira; C. Garcia \& J. Ghazoul (2016). Agroforestry coffee production increased by native shade trees, irrigation, and liming. Agronomy for Sustainaible Development, 36 (3), 1-9.

Bote (2016). Examining Growth, Yield and Bean Quality of Ethiopian Coffee Trees: Towards Optimizing Resources and Tree Management. PhD Thesis. Wageningen University, Wageningen, Netherlands. 
Bukomeko, H.; L. Jassogne; G.H. Kagezi; D. Mukasa \& P. Vaast (2018). Inûuence of shaded systems on Xylosandrus compactus infestation in Robusta coffee along a rainfall gradient in Uganda. Agricultural and Forest Entomology, 20, 327-333.

Chemura (2017). Modelling Spatial Variability of Coffee (Coffea arabica L.) Crop Condition with Multispectral Remote Sensing Data. PhD Thesis. University of KwaZulu-Natal, Pietermaritzburg, South Africa.

Delaroza, F.; M. Rakocevic; G.B. Malta; P.M. Sanchez; R.E. Bruns \& I.S. Scarminio (2017). Factorial design effects of plant density, pattern and light availability on the caffeine, chlorogenic acids, lipids, reducing sugars and ash contents of Coffea arabica L. beans and leaves. Analytical Methods, 9, 3612-3618.

De Pascale, S.; L. Dalla Costa; S. Vallone; G. Barbieri \& A. Maggio (2011). Increasing water use efficiency in vegetable crop production: From plant to irrigation systems efficiency. HortTechnology, 21, 301-308.

Dobo, B.; F. Asefa \& Asfaw (2018). Effect of treeenset-coffee based agro-forestry practices on arbuscular mycorrhizal fungi (AMF) species diversity and spore density. Agroforestry Systems, 92, 525-540.

Egonyu, J.P.; J. Baguma; I. Ogari; G. Ahumuza; S. Kyamanywa; P. Kucel; G.H. Kagezi; M. Erbaugh; N. Phiri; B.J. Ritchie \& W.W. Wagoire (2015a). The formicid ant, Plagiolepis sp., as a predator of the coffee twig borer, Xylosandrus compactus. Biological Control, 91, 42-46.

Egonyu, J.P.; P. Kucel; G. Kagezi; J. Kovach; I. Rwomushana; M. Erbaugh; R. Wekono; D. Salifu \& S. Kyamanywa (2015b). Coffea arabica variety KP423 may be resistant to the Cerambycid coffee stemborer Monochamus leuconotus, but common stem treatments seem ineffective against the pest. African Entomology, 23, 68-74.
Ferguson, M.; I. Rabbi; D.J. Kim; M. Gedil; L.A.B. Lopez-Lavalle \& E. Okogbenin (2011). Molecular markers and their application to cassava breeding: past, present and future. Tropical Plant Biology, 5, 95-109.

Ferrão, R.G.; A.F.A. da Fonseca; M.A.G. Ferrão \& L.H. de Munar (2019). Conilon Coffee. $3^{\text {rd }}$ Edition updated and expanded edition. Capixaba Institute for Research, Technical Assistance and Rural Extension, Brazil.

Frasca, A.C.; M. Ozores-Hampton; J. Scott \& E. McAvoy (2014). Effect of plant population and breeding lines on freshmarket, compact growth habit tomatoes growth, flowering pattern, yield, and postharvest quality. Horticultural Science, 49, 1529-1536.

Geneti, D. (2019). Review on heterosis and combining ability study for yield and morphological characters of coffee (Coffea arabica L.) in Ethiopia. Journal of Environment and Earth Science, 9, 24-29.

ICO (2021). Exports of all forms of coffee by exporting countries to all destinations. In: Statistics on Coffee. International Coffee Organisation (ICO). London, United Kingdom.

ICO \& UCDA (2019). Country coffee profile: Uganda. International Coffee Organization (ICO) and Uganda Coffee Development Authority (UCDA).

Kagezi, G.H.; P. Kucel; J. Kobusingye; L. Nakibuule; R. Wekhaso; G. Ahumuza; P. Musoli $\&$ A. Kangire (2013). Influence of shade systems on spatial distribution and infestation of the black coffee twig borer on coffee in Uganda. Uganda Journal of Agricultural Sciences, 14, $1-12$.

Kagezi, G.H.; P. Kucel; J.P. Egonyu; L. Nakibuule; J. Kobusinge; G. Ahumuza; R. Matovu; S. Nakendo; H. Luzinda; C.P. Musoli; A. Kangire \& B.F. Chesang (2015a). Impact of the black coffee twig borer and farmers' coping mechanisms in Uganda. In: $11^{\text {th }}$ African Crop Science 
Proceedings for the Sowing innovations for sustainable food and nutrition security in Africa, African Crop Science Society, Entebbe, Uganda.

Kagezi, G.H.; P. Kucel; J.P. Egonyu; S. Kyamanywa; J. Karungi; F. Pinard; J. Jaramillo; P.J.A. van Asten; W.W. Wagoire \& H. Ngabirano (2014). A review of the status and progress in management research of the black coffee twig borer, Xylosandrus compactus (Eichhoff) in Uganda. 25 $5^{\text {th }}$ International Conference on Coffee Science, Association Scientifique Internationale du Café, Armenia, Colombia.

Kagezi, G.H.; P. Kucel; S. Olal; F. Pinard; J. Seruyange; P. Musoli \& A. Kangire (2015b). In vitro inhibitory effect of selected fungicides on mycelial growth of ambrosia fungus associated with the black coffee twig borer, Xylosandrus compactus Eichhoff (Coleoptera: Curculionidae) in Uganda. African Journal of Agricultural Research, 10, 2322-2328.

Kibirige-Ssebunya, I.; M. Nabasirye; J. Matovu \& P. Musoli (1993). A comparison among various Robusta coffee (Coffea canephora Pierre) clonal materials and their seedling progenies at different levels of nitrogen. Uganda Journal of Agricultural Sciences, 1, 5-12.

Labouisse, J.P.; B. Bellachew; S. Kotecha \&B. Bertrand (2008). Current status of coffee (Coffea arabica L.) genetic resources in Ethiopia: implications for conservation. Genetic Resources and Crop Evolution, 55, 1079-1093.

Legg, J.P.; S.C. Jeremiah; H.M. Obiero; M.N. Maruthi; I. Ndyetabula; G. Okao-Okuja; H. Bouwmeester; S. Bigirimana; W. Tata-Hangy; G. Gashaka; G. Mkamilo; T. Alicai \& P.L. Kumar (2011). Comparing the regional epidemiology of the cassava mosaic and cassava brown streak virus pandemics in Africa. Virus Research, 159, 161-170.

Leroy, T.; F. De Bellis; H. Legnate; P. Musoli; A. Kalonji; R.G. Loor Solórzano \& P. Cubry (2014). Developing core collections to optimize the management and the exploitation of diversity of the coffee Coffea canephora. Genetica, 142, 185-199.

Luzinda, H.; M. Nelima; A. Wabomba; A. Kangire; P.C. Musoli \& R. Musebe (2016). Farmer awareness, coping mechanisms and economic implications of coffee leaf rust disease in Uganda. Uganda Journal of Agricultural Sciences, 16, 207.

Magina, F.L.; D.L. Kilambo; A.P. Maerere \& J.M. Teri (2016). Innovative strategies for control of coffee insect pests in Tanzania: a review. Journal of the Open University of Tanzania, 22, 1-9.

Matovu, R.J.; A. Kangire; N.A. Phiri; G.J. Hakiza; G.H. Kagezi \& P.C. Musoli, (2013). Ecological factors influencing incidence and severity of coffee leaf rust and coffee berry disease in major Arabica coffee growing districts of Uganda. Uganda Journal of Agricultural Sciences, 14, 87-100.

Mekonnen, B.; S. Temeteme; E. Getachew; H. Kifelew \& T. Shimber (2018). Determination of appropriate planting space and vertical numbers for hybrid Arabica coffee at Yeki District, Southwestern Ethiopia. Journal of Horticulture, 6, 328-335.

Merot L'anthoene, V.; R. Tournebize; O. Darracq; V. Rattina; M. Lepelley; L. Bellanger; C. Tranchant Dubreuil; M. Coulée; P. Pégard; S. Metairon; C. Fournier; P. Stoffelen; S.B. Janssens; C. Kiwuka; P. Musoli; U. Sumirat; H. Legnaté; J. Kambale; J.Ferreira da Costa Neto; C. Revel; A. de Kochko; P. Descombes; D. Crouzillat \& V. Poncet (2019). Development and evaluation of a genome-wide coffee 8.5K SNP array and its application for high-density genetic mapping and for investigating the origin of Coffea arabica L. Plant Biotechnology Journal, 17, 1418-1430.

Musoli, C.P.; F. Pinard; A. Charrier; A. Kangire; G.M. ten Hoopen; C. Kabole; J. Ogwang; D. Bieysse \& C. Cilas (2008). Spatial and temporal analysis of coffee wilt disease 
caused by Fusarium xylarioides in Coffea canephora. European Journal of Plant Pathology, 122, 451-460.

Musoli, P.; P. Cubry; P. Aluka; C. Billot; M. Dufour; F. De Bellis; D. Pot; D. Bieysse; A. Charrier \& T. Leroy (2009). Genetic differentiation of wild and cultivated populations: diversity of Coffea canephora Pierre in Uganda. Genome, 52, 634-646.

Musoli, P.C.; A. Kangire; T. Leroy; A. Nabaggala; S. Nakendo; S. Olal; J. Ochugo; C. Kabole; J. Pande; C. Cilas; A. Charrier; D. Bieysse; J.A. Ogwang \& D.T. Kyetere (2019). Towards a variety resistant to coffee wilt disease (CWD): a case for Robusta coffee (Coffea canephora) in Uganda. P. 1472-1479. In: Conilon Coffee. Capixaba Institute for Research, Technical Assistance and Rural Extension, Brazil.

Musoli, P.C.; C. Cilas; D. Pot; A. Nabaggala; S. Nakendo; J. Pande; A. Charrier; T. Leroy \& D. Bieysse (2013). Inheritance of resistance to coffee wilt disease (Fusarium xylarioides Steyaert) in Robusta coffee (Coffea canephora Pierre) and breeding perspectives. Tree Genetics and Genomes, 9, 351-360.

Njoroge, J.M.; K. Waithaka \& J.A. Chweya (1992). The influence of tree training and plant density on growth, yield components and yield of Arabica coffee cv. Ruiru 11. Journal of Horticultural Science, 67, 695-702.

Owere, L.; P. Tongoona; J. Derera \& N. Wanyera (2014). Farmers' perceptions of finger millet production constraints, varietal preferences and their implications to finger millet breeding in Uganda. Journal of Agricultural Science, 6.

Pereira, S.P.; D.P. Baliza; M.O. Santos; J.D. Alves \& R.J. Guimarães (2013). Influence of cultivation spacing and two pruning times on stem carbohydrate levels in coffee. Coffee Science, 8, 460-468.

Rakocevic, M.; F.T. Matsunaga; M.P. Novaes; R.S. Oyamada; M.B.S. Scholz; S. Griffon; J. Dauzat \& E. Costes (2014). How density and planting pattern affect coffee plant structure and berry distribution in ûrst production year?. In: $25^{\text {th }}$ International Conference on Coffee Science at the $25^{\text {th }}$ International Conference on Coffee Science, Association Scientiûque Internationale du Café, Armenia, Colombia.

Razaq, M.; S. Maqsood; M. Aslam; S.A. Shad \& M. Afzal (2012). Effect of plant spacing on aphid population, yield components and oil contents of late sown canola, Brassica napus L. (Brassicaceae). Pakistan Journal of Zoology, 44, 991-995.

Rezende, F.C.; A.L.D. Caldas; M.S. Scalco \& M.A. de Faria (2014). Leaf area index, plant density and water management of coffee. Coffee Science, 9, 11.

Rodrigues, W.N.; M.A. Tomaz; A.G. Ferrão; T.V. Colodetti; M.A. Apostólico \& L. Fardim (2014). Biometrical studies on characteristics of plagiotropic branches in Coffea arabica L. cultivated with high plant density. Australian Journal of Crop Science, 8, 1239-1247.

Rodrigues, W.N.; M.A. Tomaz; M.A.G. Ferrão; L.D. Martins; T.V. Colodetti; S.V.B. Brinate; J.F.T. Amaral; F.M. Sobreira \& M.A. Apostólico (2016). Biometry and diversity of Arabica coffee genotypes cultivated in a high-density plant system. Genetics and Molecular Research, 15, $1-12$.

Sseremba, G.; G.H. Kagezi; J. Kobusinge; P. Musoli; D. Akodi; P. Kucel; J. Chemutai; J. Mulindwa \& G. Arinaitwe (2021). High Robusta coffee plant density is associated with better yield potential at mixed responses for growth robustness, pests and diseases: which way for a farmer? Australian Journal of Crop Science, 15, 494-503.

Sseremba, G.; P. Tongoona; J. Eleblu; E.Y. Danquah \& E.B. Kizito (2018). Heritability of drought resistance in Solanum aethiopicum Shum group and combining ability of genotypes for drought tolerance and recovery. Scientia Horticulturae, 240, 213-220. 
Tesfaye, S.G.; M.R. Ismail; H. Kausar; M. Marziah \& M.F. Ramlan (2013). Plant water relations, crop yield and quality in coffee (Coffea arabica L.) as influenced by partial root zone drying and deficit irrigation. Australian Journal of Crop Science, 7, 1361-1368.

UBOS (2020). Statistical abstract. Uganda Bureau of Statistics (UBOS). Kampala, Uganda.

UCDA (2019). Robusta Coffee Handbook. Uganda Coffee Development Authority (UCDA). Kampala, Uganda.

Uganda Coffee Federation (2017). The Coffee Roadmap is Launched. The Coffee Times 1. Kampala, Uganda.

Ullasa, M.Y.; T. Sheshadri; R. Nagaraj; S. Sudheendra; K. Basavaraj \& M.R. Bhavya (2014). Effect of application of farmyard manure, fertilizer levels and different plant population levels on seed yield, nutrient uptake by sunflower and final nutrient status of the soil. Trends in Biosciences, 7 , 393-395.

Wagner, S.; C. Rigal; T. Liebig; R. Mremi; A. Hemp; M. Jones; E. Price \& R. Preziosi (2019). Ecosystem services and importance of common tree species in coffee-agroforestry systems: local knowledge of small-scale farmers at Mt. Kilimanjaro, Tanzania. Forests, 10, 963.

Wang, N.; L. Jassogne; P.J.A. van Asten; D. Mukasa; I. Wanyama; G. Kagezi \& K.E. Giller (2015). Evaluating coffee yield gaps and important biotic, abiotic, and management factors limiting coffee production in Uganda. European Journal of Agronomy, $63,1-11$.

Worku, M. \& T. Astatkie (2010). Growth responses of arabica coffee (Coffea arabica L.) varieties to soil moisture deficit at the seedling stage at Jimma, Southwest Ethiopia. Journal of Food, Agriculture and Environment, 8 (1), 195-200.

$\mathrm{Wu}$ (2016). Infestation and Management of the Black Coffee Twig Borer in Uganda and the Potential Impact of the Leguminous Tree Albizia Chinensis on Robusta Coffee. BSc Dissertation. Swedish University of Agricultural Sciences, Uppsala, Sweden.

Zhang, D.; Z. Luo; S. Liu; W. Li; T. Wei \& H. Dong (2016). Effects of deficit irrigation and plant density on the growth, yield and fiber quality of irrigated cotton. Field Crops Research, 197, 1-9.

$* * 0 * *$ 